\title{
MOZÁRABES DE VALENCIA Y «LENGUA MOZÁRABE»
}

CARMEN BARCELÓ

Universidad de Valencia

El término mozárabe se ha convertido en una expresión trivial, resultado de una mención insistente y reiterada en publicaciones eruditas y divulgativas desde hace más de un siglo. A pesar de ello, lo que se sabe de cierto sobre el tema es poco, bien se trate de aspectos culturales, sociales o literarios, bien de religiosos, económicos o lingüísticos. Los estudios centrados en tierras valencianas se caracterizan - salvo excepción - por ser acumulativos (de noticias irrelevantes y analizadas con poco juicio crítico), especulativos (generalizando y atribuyendo luego a la zona lo que se supone ocurrió en el resto de la Península) y, además, poco abundantes ${ }^{1}$.

De acuerdo con la costumbre establecida por quienes se ocupan del tema, hay que comenzar por la definición y análisis del término. Tanto el ca-

\footnotetext{
1 Sin citar los capítulos o referencias en obras de carácter general, R. Chabás en los siguientes trabajos, «Los muzárabes de Valencia», El Archivo, IV, 1890, pág. 24; «Los Mozárabes valencianos», Boletín de la Real Academia de la Historia, XVIII, 1891, págs. 19-41 [hay tirada aparte: Madrid, Fortanet, 1891 y reimpresión de ésta: Valencia, Librería París-Valencia, 1980 y R. Chabás, Opúsculos. Introducció de M. Rodrigo, Valencia, Consell Valencià de Cultura, 1995, págs. 19-51]; «Los Mozárabes valencianos», El Archivo, V, 1891, págs. 628 y «Los mozárabes valencianos. Adición al P. Teixidor», en J. Teixidor, Antigüedades de Valencia, I, Valencia, 1895, págs. 391-420; F. Fernández y González, «Ampliación sobre los mozárabes valencianos», El Archivo, V, 1891, págs. 28-30 [reproducido en J. Teixidor, Antigüedades de Valencia, I, Valencia, 1895, págs. 421-439]. A un siglo vista, L. Peñarroja, Cristianos bajo el Islam. Los mozárabes hasta la reconquista de Valencia, Madrid, 1993. Con otros planteamientos críticos, M. Epalza y E. A. Llobregat, «¿Hubo mozárabes en tierras valencianas? Proceso de islamización del Levante de la península (Sharq al-Andalus)», Revista del Instituto de Estudios Alicantinos, 36, 1982, págs. 7-32 y P. Guichard, «Les mozarabes de Valence et d'al-Andalus entre l'histoire et le mythe», Revue de l'Occident Musulman et de la méditerranée, 40, 1985, págs. 17-27. Aunque se trate de una burda patraña, merece ser citada por su significación en el actual contexto valenciano la obra de J. Gironés García, Los Mozárabes Valencianos. Xàtiva Mozárabe. Estudio documentado basado en la arqueología, Xàtiva, 1983, reseñada críticamente por M. de Epalza en Sharq al-Andalus. Estudios Árabes, 1, 1984, págs. 203-206.
} 
talán mossàrab como el portugués moçárabe son palabras, adaptadas de la castellana mozárabe, de uso relativamente reciente en ambas lenguas. La etimología propuesta - aceptada de forma general- es el participio árabe musta'rib que se traduce por 'el que sin ser árabe se hace semejante a los árabes'. Los diccionarios modernos de las lenguas peninsulares recogen dos acepciones principales: cristianos que vivían en los territorios de la Península bajo el gobierno de los musulmanes; cosa de los mozárabes o que está relacionada con ellos.

Respecto a la primera, no está documentado en los textos árabes de la Edad Media el uso de la voz musta'rib para referirse a los cristianos que vivían en al-Andalus ${ }^{2}$. Se emplean los nombres nașrānī 'nazareno' y mušrik 'politeísta' que, como rūm 'romanos', aluden a creencias religiosas divergentes del Islam. Otros son términos jurídicos, como dimmi y mu 'āhad 'sometido a pacto'. En referencias colectivas el apelativo genérico empleado es 'âyam, que - como el adjetivo derivado 'âyami- señala el carácter ajeno a la comunidad arabigoislámica de cualquier cosa, concepto o individuo. Ni tan siquiera aparece este apodo para distinguir a los cristianos andalusíes deportados al norte de África en el siglo XII, pues allí se les dio otro nombre árabe introducido en castellano como farfán ${ }^{3}$.

Para definir mejor el étimo propuesto puede recurrirse al Vocabulista in Arabico del siglo XIII, atribuido sin fundamento al fraile Ramón Martí y - como consecuencia - al habla del territorio levantino. En la parte latina-árabe aparece la voz Arabicus traducida por Musta'rabi. En el vocabulario inverso árabe-latino se encuentra Musta rabi con el equivalente catalán de Alcaraviat ${ }^{4}$. Así pues, no hay ninguna alusión a las ideas o convicciones religiosas cristianas, como tampoco a cualquier lengua románica; muy al contrario, la idea básica que nos transmite este texto medieval es la de árabe con todo lo que ello implica.

No puede pasarse a la ligera sobre este punto. La pregunta que surge inmediatamente es por qué se ha silenciado esta fuente, conocida desde anti-

\footnotetext{
${ }^{2}$ Dejó constancia de ello F. Simonet, Historia de los mozárabes de España, deducida de los mejores y más auténticos testimonios de los escritores christianos y árabes, Madrid, 1903, vii-ix.

${ }^{3}$ F. Maíllo, «Precisiones para una historia de un grupo étnico-religioso: los farfanes», $\mathrm{Al}$ Qantara, IV, 1983, págs. 265-281.

${ }^{4}$ Ningún diccionario etimológico recoge esta primera documentación en árabe. Ni la recogió Simonet, ni se encuentra en otros trabajos sobre la etimología del término. Para must'arabĩ véase Vocabulista in Arabico, ed. C. Schiaparelli, Firenze, 1871, pág. 249, s.v. arabicus y pág. 185 s.v. alcaraviat; F. Corriente, El léxico árabe andalusí según el «Vocabulista in Arabico», Madrid, 1989, pág. 202 s.v. 'rb; D. A. Griffin, «Los mozarabismos del 'Vocabulista' atribuido a Ramón Martí», Al-Andalux, XXV, 1960, pág. 162 s.v. alcaraviat. En R. Menéndez Pidal, Orígenes del español, Madrid, $1976^{8}$, § 86, pág. 415, nota 1 se encuentra un lacónico «En el Vocabulario del siglo XIII se traduce 'arabicus...'».
} 
guo y tan aprovechada en lo concerniente a mozarabismos; y por qué se ha puesto tanto énfasis en matizar el significado etimológico de algarabiado, 'el que sabe lengua árabe, el que sabe algarabía', que confirman además de una manera tan evidente los abundantes documentos árabes de los mozárabes toledanos y el Vocabulista ${ }^{5}$, para reducirlo a un impersonal y paniaguado 'que se asemeja a los árabes'.

El término mozárabe no se ha podido documentar antes del siglo XI en ningún territorio peninsular. Su introducción en castellano está directamente relacionada con Toledo (así lo afirma Covarrubias en su Tesoro) y se utilizó como sinónimo del cristiano de esta ciudad que había convivido con los musulmanes. La unanimidad de las fuentes es total respecto al lugar de nacimiento de la voz y de quienes la pusieron en circulación: el territorio cristiano del Norte y sus habitantes ${ }^{6}$. También aquí vuelve a ser evidente que - para aquellas gentes - los cristianos de Toledo y, por extensión los andalusíes, estaban arabizados, eran algarabiados, esto es musta 'rabi ${ }^{7}$.

La acepción adjetiva del término mozárabe se ha usado en la actual centuria para calificar muchos supuestos. Los historiadores de la Iglesia la emplean - de manera impropia y abusiva - para señalar cuatro cosas que se documentan desde antiguo como específicas de la ciudad de Toledo:

a) La misa o liturgia isidoriana, también llamada oficio hispano-gótico, usual en todos los territorios de la Península, septentrionales y árabes, hasta que se impuso el rito romano a partir del siglo XI. El cardenal Cisneros la rescató del olvido al editarla en 1502 y trató de reimplantarla fundando con este motivo una nueva capilla en la catedral de Toledo, desde entonces llamada mozárabe. Ante la nueva pérdida de esta liturgia y su memoria, el arzobispo Lorenzana la reeditó en 1755. Por privilegio papal puede ser utilizada, de forma restringida, en Toledo y alguna otra iglesia castellana.

b) La música propia a este rito hispano-gótico, opuesta al canto gregoriano, conocida a través de cantorales toledanos.

c) La letra medieval que los paleógrafos de hoy, con mayor precisión, llaman visigótica, ya que no fue exclusiva de los cristianos andalusíes.

${ }^{5}$ Además de los ejemplos aducidos por Simonet en su Historia, xiv, notas 1-5, ver A. González Palencia, Los mozárabes de Toledo en los siglos XII y XII, Madrid, 1930, vol. preliminar, págs. 122-123 y I. Ferrando Frutos, El dialecto andalusi de la marca media. Los documentos mozárabes toledanos de los siglos XII y XIII, Zaragoza, 1995, pág. 218, s.v. 'rb.

${ }^{6}$ Aspecto señalado con fina percepción por P. Chalmeta en el artículo «mozarabes» de la Encyclopédie de l'Islam, París [2. ${ }^{\mathrm{a}}$ ed.], vol. VII.

7 Ver la sugerencia de D. Urvoy, «L'idée de "christianus arabicus"», Al-Qantara, XV, 1994, págs. 497-507 [en especial pág. 505] de que el musta rabĩ del Vocabulista y la autocalificación christianus arabicus de Ramón Llull están en el mismo plano. 
d) Los códices y manuscritos con este mismo tipo de letra que en su mayor parte se conservan -o se conservaban - en la biblioteca de la iglesia catedral de Toledo. El criterio de denominación se basa en que buena parte de ellos contienen notas marginales en letras árabes o en que se supone fueron escritos en algún lugar de al-Andalus ${ }^{8}$.

También el adjetivo mozárabe se ha venido utilizando por los historiadores del Arte ${ }^{9}$ para referirse a dos tipos de manifestaciones que se piensan pudieron ser producidos por cristianos huidos hacia el Norte desde tierras islámicas:

a) Un tipo de iglesia que se caracteriza por la presencia de elementos arquitectónicos de estilo árabe, como el arco de herradura. Estos edificios, construidos entre los siglos IX y X, pueden verse en tierras de León, Casti1la, Asturias, norte de Portugal, Galicia, Navarra, Aragón, en la Cataluña norte y muy raramente en Andalucía.

b) Los relicarios, cruces y otros objetos litúrgicos de aquellas iglesias, así como las iluminaciones de los manuscritos denominados beatos, cuyos artesanos emplearon principios artísticos árabes, como puede verse en sus dibujos y decoraciones, incluso con letras árabes.

Fuera del uso abusivo del adjetivo mozárabe para hablar de la música, de la paleografía y del rito hispano-gótico, en el resto de aplicaciones hay un elemento común: el carácter árabe que se atribuye a cosas específicamente cristianas, como son las iglesias, los objetos litúrgicos y los libros religiosos manuscritos. Se trata, pues, de influencias culturales arábigas y, en la mayor parte de los casos, no hay pruebas de la participación activa de cristianos andalusíes en estas obras ${ }^{10}$.

\footnotetext{
${ }^{8}$ Cfr. Historia de la Iglesia en España, ed. R. García-Villoslada, Madrid, 1982 y Diccionario de Historia Eclesiástica de España, Madrid, 1972, bajo diversas entradas. Sobre la música, C. Rojo y G. Prado, El canto mozárabe, Barcelona, 1929 y I Congreso Internacional de Estudios mozárabes. Liturgia y Música (Toledo, 1975). Toledo, 1976. Sobre manuscritos, R. Gonzálvez Ruiz, «Noticias sobre códices mozárabes en los antiguos inventarios de la Biblioteca Capitular de Toledo», Historia Mozárabe. Primer Congreso Internacional de Estudios Mozárabes (1975), Toledo, 1978, págs. 45-78 y M. Díaz y Díaz, De Isidoro al siglo XI. Ocho estudios sobre historia literaria peninsular, Barcelona, 1976. También en Toledo se usó «mozárabe» como título de hidalguía; véase Genealogías mozárabes. I Congreso Internacional de Estudios Mozárabes (1975), Toledo, 1981.

${ }^{9}$ El uso fue instaurado por M. Gómez Moreno en su obra titulada Iglesias mozárabes, Madrid, 1919 (Granada, 1975) y Ars Hispaniae III. El arte árabe-español hasta los almohades. Arte mozárabe, Madrid, 1954.

${ }^{10}$ Resulta significativo lo que dice M. Maintre (en El estilo mozárabe. La pintura cristiana hispánica en torno al año 1000, Madrid, 1994, págs. 13-14) para justificar el título de su obra: aun siendo un término arbitrario, es útil porque evita perífrasis del tipo «estilo neovisigótico» y «estilo de repoblación» usado por otros autores.
} 
Mozárabe adjetiva también una supuesta lengua: la que se pretende que hablara aquella comunidad. No es nada fácil encontrar esta acepción en los diccionarios castellanos y portugueses, pero sí aparece en los estudios filológicos sobre la historia de las lenguas románicas peninsulares. Es en el ámbito de la lengua catalana donde en el artículo 'mossàrab' del Dicciona$r i$ de Alcover y Moll (1926-1968) se recoge por primera vez esta definición: 'parlar romànic dels indígenes hispànics durant la dominació musulmana'. Corominas no la recoge en su DECLC (1980-1991), aunque en esta obra son muy abundantes las citas a influencias mossàrabs o del dialecte romànic mossàrab ${ }^{11}$.

Por último, el adjetivo se encuentra usado en relación con la Literatura española. Se denomina lírica o poesía mozárabe a un volumen muy escaso de materiales, arbitrariamente reconocidos en los versos finales de composiciones árabes y hebreas; otros prefieren llamar a estos versos «jarchas romances». Aunque hay cierto consenso en la identificación de esos materiales con palabras de los romances peninsulares, no existe ninguna noticia que vincule estos versos con poetas cristianos andalusíes.

En resumen, se observa que mozárabe se ha introducido en el ámbito científico como referente genérico a los cristianos de al-Andalus (aunque su uso estaba sólo documentado por la ciudad de Toledo) y a cualquier cosa relacionada con ellos, incluso la lengua (aunque el término se utilizara en lo antiguo como sinónimo de algarabiado). Se ha producido así una situación embarazosa que plantea la necesidad de sustituir, poco a poco y en algunos campos de estudio, la impropia denominación de «mozárabe» por otras más acordes (caso de los paleógrafos, de los historiadores de la Iglesia y del Arte, de algunos filólogos).

Puede que el término sea adecuado para definir y caracterizar cosas y personas influidas por la cultura arábiga; pero no lo es para hacer distingos entre cristianos (al Norte libres e innovadores; al Sur sometidos a los árabes y conservadores) ni entre lenguas románicas (al Norte más evolucionadas y limpias; al Sur más primitivas y contaminadas). Es, además, término muy poco apropiado y tendencioso como referente de la inmutable «esencia del ser español». Y si se observa bien, funciona como el humo que todo lo tizna.

\footnotetext{
11 Estas citas se hacen para justificar la evolución fonética a partir de sus propuestas etimológicas. Han sido muchas las voces que han criticado este "furor mozárabe» del filólogo catalán. Como muestra, J. Massot i Muntaner, «"Primetxer”, un mossarabisme mallorquí?», La Corona d'Aragó $i$ les llengües romàniques. Miscel.lània d'homenatge per a Germà Colon, Tübingen, 1989, págs. 435-440.
} 


\section{LOS MOZÁRABES EN LA HISTORIA DE LA IGLESIA VALENCIANA}

Atendiendo a la ya citada definición de cristiano andalusí que se da a mozárabe, se analizará ahora el tema en relación con la historia de la Iglesia valenciana. Es preciso ir con cuidado respecto a la tradicional tendencia de la historiografía eclesiástica - hecha por los eclesiásticos- a tener cierta indulgencia con las fábulas, leyendas, interpolaciones y falsificaciones interesadas. Muy a menudo se presentan como ingenuidades de los autores y su malicia es minimizada ante el fondo de verdad que tendrían muchas de estas historias.

Algunas tradiciones devotas valencianas tuvieron origen en el siglo XIII, cuando Jaime I conquistó con sus tropas las tierras islámicas del sur. Son hechos milagrosos cuya explicación pasa por una intervención divina y el aceptarlos depende del grado de creencia que cada uno tenga, pues no son dogma de fe. Se pueden recordar, entre otras, las apariciones: de san Jorge en El Puig y en Alcoi; de la sangre de Jesucristo en los corporales de Llutxent que hoy se conservan en Daroca; de unos ángeles que señalan el lugar del martirio de san Bernardo, santa Gracia y santa María en Alzira; además de la identificación de la prisión de san Vicente junto a la curia de Valencia y, en el término de Raiosa, del lugar donde fue enterrado el mártir en el siglo IV ${ }^{12}$.

Es fácil ponerse de acuerdo en que éstas y otras apariciones o descubrimientos sobrenaturales responden a una lucha colectiva - tal vez insconsciente- por cristianizar un territorio ambientalmente islámico, por darle unos referentes cristianos, por enraizar y atraer a él efectivos humanos fuertemente motivados por el cristianismo.

$\mathrm{Si}$ bien es cierto que de casi todos estos hechos extraordinarios se pueden encontrar testimonios desde casi el mismo momento de la conquista, ninguna de estas pruebas resiste la crítica más benigna. Ni tan siquiera podemos constatar, por ahora, que realmente existió san Vicente de la Roqueta ${ }^{13}$; ni en absoluto puede admitirse que Ahmet, después Bernat, y sus hermanas Zoraida y Zaida vivían en Carlet y fueron martirizados en Alzira ${ }^{14}$; como tampoco se puede admitir que existió san Pedro Pascual, obispo de

\footnotetext{
12 Todos estos hechos maravillosos aparecen ya en el cronista valenciano P. A. Beuter, Crònica. Primera part, València, 1538 [intr. y ed. de E. Iborra, Valencia, 1982].

13 E. A. Llobregat, La primitiva cristiandat valenciana, València, 1977, págs. $53-54$ y 142-143.

${ }^{14}$ La primera versión de estos martirios, realizados por orden de otro hermano de los santos llamado Almanzor, parece estar en P. A. Beuter, Crònica. Primera part, València, 1538, cap. xix [ed. cit., págs. 267 y ss.]. No señala esta fuente B. Morgades, Historia de Poblet, Barcelona, 1948, págs. 45-46.
} 
Jaén y mártir en Granada ${ }^{15}$. Es cierto que la historiografía eclesiástica más seria sólo admite estas narraciones como tradiciones piadosas y no como hechos verídicos. Pero la verdad es que sobre santos mozárabes valencianos anteriores al siglo XIII o posteriores al VIII no existe ninguna noticia. A pesar del consenso sobre la falsedad de estos datos como prueba histórica, hay quien los sigue aportando al debate científico como si tratara de verdades irrefutables.

Hace tiempo que los estudiosos aducen narraciones latinas del traslado de los restos mortales del mártir Vicente como prueba de cierta continuidad eclesiástica en tiempos islámicos. Como los autores de estos relatos querían hacerlos pasar por auténticos, en todos los casos estamos ante nombres de obispos, de reyes o de acontecimientos bien conocidos por los cristianos; pero es muy sintomática la falta de precisión en nombres o sucesos arabigomusulmanes. Según estas narraciones, los santos huesos viajaron desde Valencia hasta Portugal (Cabo de San Vicente en 760), Grecia (Creta antes del 824), Francia (Castres [Albi] en 855) e Italia (Capua en 970 y Bari después de 1087), sólo desde el siglo VIII hasta el XI ${ }^{16}$. Escolano afirmó en 1610 que en la catedral de Valencia había un brazo del santo y que el otro se guardaba en Zaragoza ${ }^{17}$. Si añadimos el que fue trasladado solemnemente desde Bari a Valencia en 1970, hay que preguntarse ¿cuántos brazos tenía el levita Vicente?

Existen otros testimonios considerados por los historiadores de la Iglesia más ajustados a la realidad, ya que se contienen en diplomas y cartularios. Tal sería el caso del documento más antiguo que probaría la presencia de núcleos cristianos en tierras valencianas: el consentimiento del príncipe musulmán de Denia, 'Alī bn Muỹāhid, para que el obispo de Barcelona pudiera ejercer su tarea pastoral entre los cristianos de las Baleares, Denia y Orihuela desde 1057. Ha sido considerado verídico por algunos, mientras

15 J. Riera i Sans, «La invenció literària de sant Pere Pasqual», Caplletra. Revista de Filologia, 1, 1986, págs. 45-60.

${ }^{16}$ Un breve resumen con bibliografía en C. Barceló, Minorías islámicas en el país valenciano. Historia y dialecto, Madrid-Valencia, 1984, pág. 128. Hay noticias de otros traslados a Monembasie (siglo x) y Metz que recoge V. Saxer, «Le culte de S. Vicent dans la Peninsule Hispanique avant l'an mil», IV Reunió d'arqueologia cristiana hispànica, Barcelona, 1995, pág. 143. Cfr. también C. García Rodríguez, El culto de los santos en la España romana y visigoda, Madrid, 1966, pág. 261, que omite el traslado a Grecia pero consigna otros. En la ya citada obra de L. Peñarroja, Cristianos bajo el Islam se silencian los conocidos traslados a Portugal, Francia, Grecia y Capua, analizando únicamente los datos sobre Bari a los que se concede valor histórico.

${ }_{17}$ Gaspar Escolano, Decada Primera de la Historia de la Insigne y Coronada Ciudad y Reyno de Valencia, Valencia, 1610 [facsímil, Valencia, 1972], libro v, cap. iii.7, col. 905 y libro II, cap. vii.6, col. 272. 
otros plantean serias dudas sobre su autenticidad ${ }^{18}$. Todo esto usando sólo la redacción latina.

De la llamada «suscripción árabe» sólo se dispone en la actualidad de la traducción de una de las dos copias existentes ${ }^{19}$. Es importante destacar que el notario que dio validez a la copia en el siglo XIII nada dice sobre ello; ni siquiera mencionó - como era su deber- 'que en el original hubiera alguna raya escrita en letra árabe. ¿Podría tratarse de una falsificación? Creo que sí. Baste decir ahora a este propósito que las dos copias del original perdido presentan diferencias, tanto en la redacción como en los nombres de los testigos y en la fecha islámica que, además, no coincide con la cristiana ${ }^{20}$.

En cuanto a las donaciones de monasterios, conventos y obispados antes de la entrada de Jaime I en el territorio valenciano, se conoce la confirmación hecha por este rey a los monjes de Poblet de un lugar en El Puig que les había prometido Alfonso. II de Aragón en 1176 para cuando se ganara el territorio ${ }^{21}$. Fuera de ésta, que no implica población cristiana bajo dominio islámico, se aducen un total de ocho, entre donaciones reales (castellanas, aragonesas y catalanas) y confirmaciones papales, desde 1167 hasta 1240 , del monasterio e iglesia de san Vicente de la Roqueta ${ }^{22}$. Para quien esto escribe, dichas donaciones no demuestran la existencia de un monasterio e iglesia en Valencia. En todo caso prueban la gran veneración al santo entre los cristianos del Norte y sus intereses —eclesiásticos y políticos-

\footnotetext{
${ }^{18}$ Véase la historia de la crítica del documento en M. Barceló, «La qüestió dels documents d'un suposat acord entre 'Alī b. Mujāhid de Dāniya i el bisbe Guislabert de Barcelona», Revista del Instituto de Estudios Alicantinos, 39, 1983, págs. 7-29, reed. en Sobre Mayūrqa, Palma, 1984, págs. 13-25.

${ }^{19}$ La realizada por J. Ribera i Tarragó para R. Chabás, «Mochéhid, hijo de Yúsuf, y Alí, hijo de Mochéhid», Estudios de erudición oriental. Homenaje a D. Francisco Codera, Zaragoza, 1904, págs. 428-430. Sin señalar que se trata de la traducción de Ribera, la reproduce L. Peñarroja, Cristianos bajo el Islam, nota 40 bis, págs. 78-79.

${ }^{20}$ Los jueces pontificios del proceso en el que se adujo el documento advirtieron - con razón - que los ejemplares carecían de los requisitos diplomáticos de autenticidad y por ello el alegato no fue tenido en cuenta. Por razones de espacio no presento aquí las pruebas que demuestran que las copias del documento, desde el punto de vista de la parte árabe, son una falsificación. Espero poder presentarlas en otro lugar.

${ }^{21}$ La donación de Alfonso II figura en el Llibre Blanc de Poblet, cfr. M. Gual Camarena, Precedentes de la Reconquista valenciana, Valencia, 1953, págs. 225-226, docs. XXVIIIXXIX. La de Jaime I de 1240 puede verse en A. Huici y M. D. Cabanes, Documentos de Jaime I de Aragón, II, Valencia, 1976, n. ${ }^{\circ}$ 316, págs. 81-82.

${ }^{22}$ Una revisión crítica de estos textos y la historia de los primeros cincuenta años de este monasterio, iglesia y hospital de S. Vicente puede verse en R. I. Burns, «Un monasteriohospital del siglo XIII: San Vicente de Valencia», Anuario de Estudios Medievales, IV, 1967, págs. 75-108 y El reino de Valencia en el siglo XIII (Iglesia y sociedad), II, Valencia, 1982, cap. xv, págs. 617-661.
} 
por conseguir una mejor posición frente a otros reinos en el momento de la conquista de Valencia a los musulmanes.

De las diversas donaciones a san Vicente, podemos eliminar una: la de Alfonso VIII de Castilla de 1167. El texto latino no permite relacionar con Valencia a los monjes favorecidos, pues de hecho sólo dice «concedo Deo et martiri Cristi Vincencio de Valencia, et omnibus fratibus eiusdem martiris ecclesie servientibus» y es evidente que sólo el santo es de Valencia, no los frailes ni la iglesia ${ }^{23}$. De otra parte, dado que las de 1177 y 1212, contenidas en los cartularios del monasterio de san Juan de la Peña, no se citan en otras posteriores, se ha sospechado de su autenticidad, puesto que los documentos de este monasterio «presentan una de las series más abundantes en falsificaciones», como dice Ubieto ${ }^{24}$. En resumen, tres de ellas no prueban nada. Las cinco restantes tampoco. Como ha demostrado Burns ${ }^{25}$, son donaciones y confirmaciones papales de un edificio y anejos construidos tras la conquista.

Tal y como ha sido señalado por diferentes autores, resulta enigmático no encontrar referencias a los cristianos andalusíes de este territorio en el siglo XIII. Nada dicen sobre ellos los numerosos diplomas y documentos reales, notariales y eclesiásticos de esta época conservados, ni la autobiografía del rey Don Jaime, ni crónicas como la de Muntaner, tan cercanas a las acciones de conquista. Tampoco hay testimonios en el pleito entre Toledo y Tarragona por el obispado de Valencia ${ }^{26}$. ¿Será que no había?

También se ha elucubrado sobre la continuación de los obispados valencianos. El dato más antiguo sería la existencia de un obispo de Elche que

\footnotetext{
${ }^{23}$ Resultan muy instructivas las observaciones hechas al documento por A. García, «L'enigma històric de San Vicent de la Roqueta», L'Espill, 17/18, 1983, págs. 113-126, al margen de que acepte la tradicional identificación de esta iglesia con la de Valencia. Las alquerías donadas las localiza en la zona de Fuentidueña del Tajo (Madrid), ya en el límite con Cuenca, en ese momento frontera cristiana con el Islam. Sobre la no supervivencia de cenobios cristianos en territorio valenciano durante el período islámico, A. Linage Conde, «El monacato en el País Valenciano hasta la Reconquista», Primer Congreso de Historia del País Valenciano, II, Valencia, 1980, págs. 377-386.

${ }_{24}$ A. Ubieto, Cartulario de San Juan de la Peña, I, Valencia, 1962, pág. 8. No existe la donación de 1172, citada por Briz y Zurita, que aduce ahora como una más L. Peñarroja, op. cit., págs. 166 y 180. Es la misma que otros historiadores sitúan en 1177 (cfr. Gual Camarena, op. cit., doc. $\mathrm{xxx}$ ).

${ }_{25}$ R. I. Burns, «Un monasterio-hospital...», Anuario de Estudios Medievales, 4, 1967, págs. $75-108$

${ }_{26}$ Ibidem, pág. 78 ; cfr. además R. I. Burns, «La muralla de la llengua: el problema del bilingüisme i de la interacció entre musulmans i cristians», en Jaume $I$ i els valencians del segle XIII, Valencia, 1981, págs. 303 y ss. La ausencia de testigos «mozárabes» en el pleito episcopal ha causado extrañeza a historiadores locales como Monzó Nogués; véase su «Estudio del topónimo Roqueta», Anales del Centro de Cultura Valenciana, 8, 1947, pág. 127.
} 
asiste a un concilio celebrado en Córdoba, convocado bajo la presión del gobierno islámico a mediados del siglo IX. Esta extravagancia (nada se vuelve a saber de este obispado) es posible que responda a un error de copia de los manuscritos, transformando en Ilicitanus lo que pudo ser un Iliberitanus, esto es de Elvira (Granada), teniendo en cuenta que el resto de los obispos presentes procedían de la Bética ${ }^{27}$.

Ante este silencio de las fuentes, resulta por de más sorprendente que el último recuento - hecho no hace mucho ${ }^{28}$ - ofrezca un total de cinco obispos en la Valencia dominada por el Cid. Aunque se advierta que ni Don Jerónimo de Perigord, ni el obispo del rey Alfonso de Castilla ni otro procedente de Albarracín son valencianos, resulta extraño que haya al mismo tiempo dos obispos naturales del país: el que se llevó a Bari el tercer brazo de san Vicente y aquel que la Primera Crónica General, redactada en la Toledo del siglo XIII, llama çaeit almatran.

El nombre, según los que'se lo creen, sería en árabe 'señor metropolitano' ${ }^{29}$. El problema es que Valencia no ha sido arzobispado hasta mucho tiempo después y que la crónica del arzobispo de Toledo y promotor del pleito de esta sede contra Tarragona, Rodrigo Jiménez de Rada (12131247), da este mismo nombre (Sa $\mathrm{i} d$, el metropolitano) a Juan «muy sabio en la lengua arábiga» ${ }^{30}$, comentarista en árabe de los evangelios y obispo de Sevilla, ciudad que ha sido arzobispado desde tiempo inmemorial. Así pues, sólo quedaría constancia documental de un arzobispo valenciano en el siglo XI e incluso sobre éste planea la sospecha de haber sido inventado de manera interesada.

27 J. Gil, Corpus scriptorum muzarabicorum, II, Madrid, 1973, pág. 553 y F. J. Simonet, op. cit., pág. 493. Enviaron sus cartas o asistieron a Córdoba en 862 los de Mérida, Baeza, Cabra, Écija, Baza, Pechina-Almería y Medina-Sidonia.

${ }^{28}$ L. Peñarroja, op. cit., págs. 87-121.

${ }^{29}$ Primera Crónica General o sea Estoria de España, que mandó componer Alphonso el Sabio y se continuaba bajo Sancho IV en 1289, ed. R. Menéndez Pidal, Madrid, 1906 [rep. Madrid, 1977, con estudio de D. Catalán], II, pág. 565a. La versión árabe correcta de «señor metropolitano» implica un artículo para «çaeyt» que no tiene y haría falta explicar adecuadamente la secuencia gráfica <aey> si, como se pretende, procede del árabe /sayyid/.

30 «Joannes episcopus qui ab arabibus Çaeyt Almatran vocabatur et magna scientia in lingua arabiga clauit». Cfr. R. Jiménez de Rada, De rebus Hispaniae, lib. iv, cap. iii. También reproduce este pasaje la Primera Crónica General (cap. 571, pág. 326a). Es posible que a partir del texto del arzobispo toledano sus contemporáneos entendieran que obispo se decía en árabe çaeyt almatran. Sobre Juan, el arzobispo sevillano del siglo IX, véase Simonet, op. cit., págs. 320-325 y sobre su posible identificación con Iohannes Hispalensis, el conocido traductor del siglo XII, cfr. P. Sj. van Koningsveld, The Latin-Arabic glossary of the Leiden University Library. A contribution to the study of Mozarabic manuscripts and literature, Leiden, 1977, págs. 51-52. 


\section{LOS CRISTIANOS DE LAS CRÓNICAS ÁRABES}

Dejando a un lado la historia de la Iglesia valenciana, llena de fantasías mozárabes, las fuentes árabes medievales aluden a los cristianos del territorio valenciano en dos ocasiones y vale la pena hacer mención de ello nuevamente. La más antigua corresponde precisamente a la época del Cid. Entonces, entre 1094 y 1101, un autor musulmán coetáneo menciona a los cristianos locales que tenían pacto con los árabes (rūm baladiyyūn 'romanos locales'/nașārà mu'āhadūn 'cristianos sometidos a pacto') que el Cid utilizaba como mediadores ${ }^{31}$. En la traducción recogida en la Primera Crónica General, en lugar de los 'cristianos locales y/o sometidos a pacto' de que habla el texto árabe, el traductor utiliza la voz 'mozárabe' que enseguida explica - para unos lectores que sabe la desconocen- eran los cristianos «criados en tierra de moros porque fueran criados con los moros et fablavan assy commo ellos et sabien sus maneras et sus costumbres» ${ }^{32}$.

La segunda mención en las fuentes árabes es del año 1126, cuando el rey Alfonso el Batallador hizo una expedición a Andalucía hasta llegar a Córdoba y Almuñécar ${ }^{33}$. Los autores que se hacen eco de ello afirman que los cristianos locales de Valencia que tenían pacto con los árabes (nașārà baladiyyūn/nașārà mu 'āhadün) se incorporaron a las tropas del rey de Aragón y señalaron los puntos débiles de la defensa islámica a su paso por Valencia, Alzira, Denia y Xàtiva. También afirman que todos los que intervinieron de manera activa, como es el caso de los valencianos, fueron expulsados al norte de África.

De estos datos se puede concluir que había comunidades cristianas, pero nada se sabe de momento sobre su número, distribución por el territorio, organización interna, lugares de culto, elementos eclesiásticos, ni sobre las actividades laborales de sus miembros. Es muy cierto que por incumplir el pacto con la autoridad islámica los responsables y sus familias fueron expulsados de al-Andalus. No se sabe el número de personas de estas tierras que pasaron a África ni las que pudo incorporar el rey Alfonso a sus tropas en la ida a Granada, ni el de familias que se llevó durante la vuelta a

${ }^{31}$ Bayān al-mugrib, ed. y trad. E. Lévi-Provençal y E. García Gómez, «La toma de Valencia por el Cid, según las fuentes musulmanas y el original árabe de la "Crónica General de España"», Al-Andalus, 13, 1948, pág. 123 [árabe] = págs. 144-145 y 125 [árabe] = pág. 147.

32 Ed. cit., cap. 918 , págs. 587a y 588 a y b.

${ }^{33}$ Esta expedición ha sido ampliamente estudiada. Analiza las fuentes cristianas y árabes A. Huici Miranda, Historia musulmana de Valencia y su región. Novedades y rectificaciones, III, Valencia, 1970, págs. 51-74. Sobre las consecuencias de esta incursión andaluza según las fuentes árabes, V. Lagardère, "Communautés mozarabes et pouvoir almoravide en $519 \mathrm{H} /$ 1125 en Andalus», Studia Islamica, LXVII, 1988, págs. 99-119, a las que hay que añadir Ibn al-Abbār, Mu'ŷam (âed. Codera), biogr. 136, pág. 155. 
Aragón. Tanto los textos árabes como los cristianos hablan de miles de mozárabes llegados a tierras africanas y norteñas.

No se encuentran más noticias de estos cristianos en las crónicas árabes. Sí las hay de los que llegaban del Norte y que los cronistas no consideran locales ni sometidos a pacto. Mencionan de forma genérica los efectivos humanos que a cambio de soldada y botín ingresaban en las tropas islámicas. Refieren, por ejemplo, la estancia del noble aragonés Blasco de Alagón y el salvoconducto que le hizo el príncipe almohade de Valencia para que pudiera ir a Marruecos y visitar al sultán. Aluden también a la presencia y martirio, por orden del mismo príncipe, de dos frailes franciscanos ${ }^{34}$.

Estos personajes, sin embargo, no son mozárabes en el sentido ya señalado de 'cristianos andalusíes sometidos a pacto', sino pisanos, genoveses, francos, catalanes, aragoneses, etc. Son «cristianos del Norte», lo mismo que los comerciantes y mercaderes que llegaban para hacer negocio ${ }^{35}$. Otros llegaban por causas más penosas, como el cautiverio: si obtenían el rescate, volvían a sus casas; si no, eran vendidos como esclavos o continuaban en cautiverio (sin derecho de organizarse ni de manifestar libremente sus creencias).

Una última consideración a este respecto. Los arqueólogos que analizan los yacimientos andalusíes, aparte de las presuntas iglesias, no han podido constatar restos que puedan ser adscritos sin ninguna duda a comunidades cristianas. $\mathrm{Y}$ esto acaece tanto en las ciudades más importantes valencianas y otras zonas rurales, como en las tierras orientales, en Andalucía o en cualquier otro lugar peninsular. Parece que su modo de vida no es fácil de diferenciar del de sus vecinos musulmanes, lo cual abundaría en el significado 'arabizado' de mozárabe. En el caso valenciano además, es nula la existencia de testimonios epigráficos latinos que pudieran ser atribuidos a estos cristianos.

\footnotetext{
${ }^{34}$ Sobre cristianos en las tropas árabes, véase el ya clásico estudio de J. Alemany, «Milicias cristianas al servicio de los sultanes musulmanes del Almagreb», Homenaje a Francisco Codera, Zaragoza, 1904, págs. 133-169. El destierro de Blasco de Alagón en E. Molina, Ceyt Abu Ceyt. Novedades y rectificaciones, Almería, 1977, págs. 21-22 y 55 [doc. 1]. Sobre este mismo acontecimiento y el martirio de los franciscanos (identificados con san Juan de Perugia y san Pere de Sistra o Sassoferrato), C. Barceló, «El sayyid Abū Zayd: príncipe musulmán, señor cristiano», Awrāq, III, 1980, págs. 103, 107 y 109, nota 84.

${ }^{35}$ Son bien conocidos los acuerdos suscritos entre los gobernantes árabes y las repúblicas italianas para el libre tránsito y establecimiento de alhóndigas para los mercaderes. En este contexto hay que colocar la cita en 1240 de «carraria illa quam mercatores christiani uti temporum sarracenorum solebant», aducida a favor de la «mozarabía» por J. Sanchís Sivera, La Diócesis valentina. Nuevos estudios históricos, Valencia, 1923, pág. 148.
} 


\section{PluRILINGÜISMO ANDALUSí Y «LENGUA MOZÁRABE»}

Como las pruebas ab silentio no demuestran nada, la falta de testimonios documentales en lengua latina no ha impedido a algunos especular y afirmar que pervivió una lengua «mozárabe» en territorio árabe valenciano. El inicio del tema se puede situar entre los años 1898 y 1936, dos fechas importantes en la Historia de España, aunque la tesis se hubiera venido gestando desde los inicios del siglo XIX, con el descubrimiento de los textos aljamiados escritos por moriscos aragoneses.

Según la hipótesis formulada por Simonet en $1888^{36}$, la lengua románica hablada en la Península a la llegada de los musulmanes se mantuvo entre la población cristiana de al-Andalus hasta la conquista de Granada en 1492. Esta tesis nunca fue cuestionada y de hecho la reforzó Ribera (en 1912 y en 1915) cuando afirmó que esa lengua románica era usada por todos los andalusíes, cristianos y musulmanes ${ }^{37}$. Puesto que los musulmanes hablaban romance, ya no era necesario continuar la investigación para probar la existencia de cristianos en al-Andalus que habrían perpetuado esa lengua desde el siglo VIII al XV. La aparente contundencia de los datos presentados por Ribera hizo enmudecer a todo el mundo. Pero, como ha dejado escrito García Gómez ${ }^{38}$, Ribera «no era propiamente filólogo, ni se paraba en nada porque iba siempre "más allá"».

Para consolidar la teoría hizo falta el concurso de Menéndez Pidal. Con los datos aportados por estos arabistas, los materiales del Glosario de Asín (1943) y las «jarchas románicas» encontradas en poesías andalusíes (1948), defendió durante años la tesis de la existencia de una unidad lingüística hispánica, basada en la presencia del mozárabe por todas partes, aunque señaló la decadencia de los núcleos cristianos en al-Andalus a mediados del siglo XII ${ }^{39}$. También estableció la teoría de la influencia del substrato en la formación y fragmentación dialectal de las lenguas románicas peninsulares.

\footnotetext{
${ }^{36}$ F. J. Simonet, Glosario de voces ibéricas y latinas usadas entre los mozárabes, Madrid, 1888 [reimpresión 1982].

37 J. Ribera, «El Cancionero de Abencuzmán» discurso de ingreso en la Real Academia Española, 1912 y «Épica andaluza romanceada» discurso de ingreso en la Real Academia de la Historia, 1915, recogidos en Disertaciones y opúsculos, I, Madrid, 1928, págs. 3-150.

${ }^{38}$ E. García Gómez, Todo Ben Quzman, III, Madrid, 1972, pág. 330.

${ }_{39}$ R. Menéndez Pidal, Origenes del español, Madrid (primera edición 1926, segunda 1929) tercera 1950 (a la que se incorporan los datos del Glosario de Asín y las jarchas) [reed. $1976^{8}$, págs. $\left.426-427\right], \S 89_{2}$. Sobre la tesis pidaliana y su influencia en la historiografia lingüística valenciana, G. Calaforra, "Sobre connotacions i implícits en la historiografia de la llengua», Miscel.lània Joan Fuster. Estudis de Llengua i Literatura, VII, Montserrat, 1993, págs. 371-391 y J. Domingues i Benlloc, «Entorn del "mossàrab" de València», Llengües en contacte als regnes de València $i$ de Múrcia (segles XIII-XV), (J. Colomina ed.), Alicante, 1995, págs. 51-68.
} 
Con ello abrió la etapa de los estudios dedicados a encontrar estas influencias substráticas y las características comunes de la denominada «lengua mozárabe» en la toponimia, la fonética y el léxico peninsulares.

La tesis propuesta hasta ahora sobre la situación lingüística a lo largo de la historia de al-Andalus ha sido la siguiente: a pesar de la influencia árabe, se habría mantenido una «lengua románica nacional», de modo similar a lo que ocurrió en la antigua Persia que, aunque se arabizó culturalmente, mantuvo sus dialectos usando desde el siglo XI el alfabeto árabe para escribirlos ${ }^{40}$. Quizá por esto Lévi-Provençal llegó a decir que los mozárabes y los nuevos conversos al Islam hicieron posible que la lengua románica hispánica se perpetuara en al-Andalus y que esta lengua, «en árabe al-'achamiyya, más tarde, en las zonas reconquistadas por los cristianos, había de escribirse en caracteres árabes, según el sistema gráfico del aljamiado» ${ }^{41}$.

En los últimos diez o quince años los estudios sobre las obras aljamiadas han puesto en evidencia que son traducciones de textos árabes hechas, doscientos años después de la conquista cristiana, casi exclusivamente por y para los musulmanes aragoneses de los siglos XV y XVI ${ }^{42}$. No se conocen textos aljamiados de los musulmanes valencianos y Burns y otros historiadores han llegado a la conclusión que éstos fueron mayoritariamente arabófonos monolingües ${ }^{43}$. Ello explica que, aunque no haya ninguna prueba de ello, se haya renovado en nuestros días el viejo postulado (negado por Menéndez Pidal entre otros) de la pervivencia de fuertes comunidades cristianas andalusíes en el siglo XIII ${ }^{44}$.

Ante la presencia de otros grupos humanos en al-Andalus, los estudio-

${ }^{40}$ El símil de Persia fue usado por J. Ribera, Disertaciones y opúsculos, I, Madrid, 1928, págs. $74-75$ y 118, nota 2, donde afirma: «En España debió pasar algo parecido a lo que ocurrió en Persia. El árabe fue la lengua oficial de la diplomacia, de la filosofía, de las ciencias, etc.; pero no pudo ser lengua popular en los primeros tiempos».

${ }^{41}$ E. Lévi-Provençal, España musulmana hasta la caída del califato de Córdoba (7111031 de J.C.). Instituciones y vida social e intelectual, vol. V de Historia de España, dirigida por R. Menéndez Pidal, Madrid, 1957, pág. 103.

${ }^{42}$ M. J. Viguera, «Introducción» a F. Corriente, Relatos pios y profanos del ms. aljamiado de Urrea de Jalón, Zaragoza, 1990, págs. 32 y ss.

${ }^{43}$ Los únicos textos aljamiados que se conocen son oraciones cristianas, cfr. A. Labarta, "Oraciones cristianas aljamiadas en procesos inquisitoriales de moriscos valencianos», Boletín de la Real Academia de Bellas Letras de Barcelona, XXXVII, 1977-78, págs. 177-197 y A. Labarta y C. Barceló, «Latín y romance en oraciones cristianas halladas a moriscos valencianos», Romania Arabica. Festschrift für Reinhold Kontzi, Tübingen, 1996, págs. 315-324. Sobre el monolingüismo árabe en Valencia, R. I. Burns, Diplomatarium of the Crusader Kingdom of Valencia. I. Society and Documentation in Crusader Valencia, Princeton, 1985, págs. 132-133, donde se recoge la bibliografia pertinente.

${ }^{44}$ Por ejemplo, sobre Granada en el siglo XIV, A. Galmés de Fuentes, Las jarchas mozárabes. Forma y significado, Madrid, 1994, pág. 82, retomando argumentos de Simonet, Historia..., págs. 788-789. Para Valencia, L. Peñarroja, Cristianos bajo el Islam. 
sos se vieron abocados a formular la tesis del plurilingüismo. Sus componentes serían árabe, hebreo, bereber, latín y lenguas románicas, aunque con diferentes niveles de empleo: árabe, hebreo y latín para usos religiosos; árabe dialectal, bereber y lenguas románicas en familia y el árabe literario como lengua de cultura de todos.

Filólogos romanistas, como Wright ${ }^{45}$, postulan hoy que durante doscientos años (siglos IX y X) se produjo en al-Andalus una situación bilingüe, pasando durante el siglo XI por una etapa muy inestable que acabó en un monolingüismo árabe de los andalusíes en el siglo XII. Estas hipótesis y otras se han emitido con los datos aportados fundamentalmente por Simonet, Ribera, Asín y García Gómez, pero sin analizarlos.

\section{ARgumENTOS A FAVOR DE «LA RAZA HISPÁNICA»}

Las hipótesis de Ribera de los años 1912 y 1915 no iban encaminadas a consolidar la de Simonet. Sólo quería explicar que la poesía popular del cordobés del siglo XII Ibn Quzmān y los topoi literarios de la conquista islámica eran productos hispánicos. Para demostrarlo le fue preciso negar que en al-Andalus hubiera elementos humanos de pura raza árabe y sostener el conocimiento general de la lengua romance. El proceso de islamización de las sociedades peninsulares fue representado con la imagen de unas gotitas de anilina roja lanzadas en el estanque de España y afirmó que el elemento árabe «entró en dosis casi infinitesimal en la química social de los musulmanes españoles» ${ }^{46}$.

No merece la pena argumentar hoy contra esta tesis. Sí es preciso hacer una referencia a los datos lingüísticos aportados al debate. No es agradable tener que decir de Ribera que o bien el ansia por consolidar su hipótesis le llevó a desvirtuar datos o no sabía tanto árabe, lo cual sería igualmente grave. Por otra parte, es muy evidente que Ribera rehuyó ofrecer cronologías, tal vez para dar a entender que se trataba de hechos constantes.

La estrategia expositiva consistió en tratar en primer lugar la cuestión racial, para concluir que existió una «raza hispana» común a todos los habitantes de al-Andalus. Después, sirviéndose de la obra de Simonet y de otras noticias, llevó el discurso al campo de la demostración del uso de una len-

${ }^{45}$ R. Wright, «Sociolinguistique hispanique ( $\mathrm{VIII}^{\mathrm{e}}-\mathrm{XI}{ }^{\mathrm{e}}$ siécles)», Médiévales. Langue. Textes. Histoire, 25, 1993, págs. 61-70. Sobre la situación de la lengua árabe en el siglo XI, H. Pérès, "Les éléments ethniques de l'Espagne musulmane et la langue arabe au $\mathrm{V}^{\mathrm{e}} / \mathrm{XI}^{\mathrm{e}}$ siècle», Études d'orientalisme dédiées à la mémoire de Lévi-Provençal, II, Paris, 1962, págs. 717-731.

46 «El Cancionero de Abencuzmán» en Disertaciones y opúsculos, I, Madrid, 1928, pág. 26. 
gua románica hasta en la corte de los califas Omeyas de Córdoba, para concluir que existió una «lengua hispana» utilizada por toda la población de las tierras peninsulares bajo el Islam ${ }^{47}$.

Por considerarlo denominación impropia y motivo de muchos errores, Ribera rechazó el adjetivo «mozárabe» dado por Simonet a ese dialecto románico ${ }^{48}$. Seguidamente formuló su tesis en estos términos: coexistieron en al-Andalus dos lenguas literarias (el árabe clásico, utilizado por todos, y el latín clásico, usado exclusivamente por el clero cristiano) y dos lenguas vulgares (árabe y latín) habladas indistintamente por las mismas personas.

Para demostrar a los lectores castellanos - que sólo tienen una- que el hecho de hablar indistintamente dos lenguas es "ordinario y natural», Ribera puso los ejemplos de Valencia, Cataluña, País Vasco, Asturias, Galicia y los judíos de Marruecos y Turquía en $1912^{49}$. La pregunta que suscita el ejemplo es ¿quién hacía de castellanos, árabes o turcos en al-Andalus? $\mathrm{O}$, dicho de otra manera: si apenas llegaron árabes de raza y todo el mundo utilizaba la lengua romance y se entendía con ella, ¿por qué se usaba el árabe vulgar?

Ribera pasó revista a los testimonios sobre el uso de la lengua románica de los eruditos y médicos andalusíes, considerando demostrado el apriorismo del mantenimiento de la «lengua nacional» de bereberes, persas o turcos y sin mencionar que no hablan árabe.

Según señalan estos autores árabes medievales, eran propias del 'àmma determinadas voces cuya etimología se puede buscar en el latín vulgar. De ello infiere Ribera que aluden al habla del pueblo y por tanto que el pueblo árabe hablaba romance. Pero como ya señaló hace años el profesor alAhwāni, 'āmma es «una palabra, que cuenta con bastantes precedentes entre los filólogos árabes». Este término no se refiere a la plebe ni al populacho, lo que hoy se llamaría 'el hombre de la calle' (como circula en los estudios sobre mozárabes), sino a los cultos e instruidos —entre los que se encontraban los poetas, secretarios, alfaquíes y gentes de diversas profesiones-, en cuyo lenguaje se introducían los defectos de la conversación común arábiga. Aún más, cuando los autores árabes cultos afirmaban que una voz determinada se decía de una forma específica «entre nosotros ('inda-nā)», no aludían al vulgo sino a ellos mismos ${ }^{50}$.

No es posible admitir el factor multiplicador que Ribera aplicaba por

\footnotetext{
${ }^{47}$ Op. cit., I, 34. Los testimonios se detienen en el siglo XI.

48 Op. cit., I, págs. 27-28.

49 Op. cit., I, pág. 29.

50 Al-Ahwānī, 'Abd al-'Azīz «Alfāz magribiyya min kitāb Ibn Hišām al-Lajmī fì laḥn al'āmma», Maŷallat Ma'had al-Majtūtât al-'Arabiyya [Revista del Instituto de Manuscritos Árabes], 3, 1957, págs. 133-135, apud J. M. Fórneas, «Introducción a la corrección del lenguaje», Anaquel de Estudios Árabes, 3, 1992, pág. 322.
} 
sistema a ejemplos únicos, excepcionales y puntuales. Así, según Ribera había muchos musulmanes que no sabían orar en árabe porque el polígrafo cordobés del siglo XI Ibn Hazm «decía de sí mismo que a los 27 años aún no había aprendido las prácticas del rezo en la mezquita» ${ }^{51}$; si uno de los señores rebeldes al califa de Córdoba en el siglo IX aparece una vez con la denominación de âyam, no se puede concluir que todos los señores rebeldes hablaban la lengua románica ${ }^{52}$.

Y si las biografías de sabios andalusíes utilizan el conocimiento o la ignorancia de la filología árabe ('arabiyya) entre los méritos o deméritos de los hombres cultos, de ello no puede extraerse la conclusión - como hizo Ribera ${ }^{53}$ - de que, lo mismo que él y otros colegas arabistas, había muchísimos musulmanes que no sabían hablar más que la lengua nacional románica, aunque supieran leer y traducir el árabe. Con razón Stern señaló que esta opinión de Ribera era exagerada, puesto que el término 'arabiyya no quiere decir solamente lengua árabe ${ }^{54}$.

Entre los datos sacados de las obras medievales, Ribera hace mención a un autor oriental del siglo $\mathrm{x}$, al-Maqdisī [también llamado al-Muqaddasi], en cuya obra geográfica habría una referencia a la lengua románica de alAndalus al describir el habla de unos informantes de estas tierras. Pues bien, tal y como la presenta Ribera, la noticia es inexacta. En primer lugar, porque el autor repite muchas veces que no visitó nuestra Península; en segundo lugar, porque nada dice de la pronunciación de sus informadores andalusíes; en fin, porque la noticia de que se hablaba un árabe confuso para un oriental y otra lengua parecida al griego moderno está referida en realidad a las tierras del norte de África ${ }^{55}$.

\footnotetext{
${ }^{51}$ «Épica andaluza romanceada» en Disertaciones y opúsculos, I, Madrid, 1928, pág. 111 y nota 1, sin ningún apoyo documental. La referencia es inexacta. Cfr. E. García Gómez, «Introducción», Ibn Hazm, El Collar de la paloma, Madrid, $1971^{3}$, pág. 33, «[el autor] nos dice que hasta los veintiséis años [...] no acometió seriamente los estudios jurídicos» [el subrayado es nuestro]. El sabio cordobés se refería a los estudios de jurisprudencia islámica, no a las oraciones en la mezquita.

52 «El Cancionero de Abencuzmán» en Disertaciones y opúsculos, I, Madrid, 1928, pág. 33, sobre Ibn Hafsūn y remitiendo a Dozy.

${ }_{53}$ Quien, además, sostiene que «para la gente latina, el aprendizaje de la lengua árabe ha debido tener siempre las mismas dificultades que ahora», cfr. Disertaciones y opúsculos, I, Madrid, 1928, págs. 111-112.

${ }_{54}$ S. M. Stern, «Les vers finaux en espagnol dans les muwašs̆ahs hispano-hebraïques: une contribution à l'histoire du muwaššạ et à l'étude du vieux dialecte espagnol "mozarabe"», $\mathrm{Al}$ Andalus, XIII, 1948, pág. 334, nota 1, recogido en Hispano-Arabic Strophic Poetry, Oxford, 1974, notas, págs. 150-151.

55 «El Cancionero de Abencuzmán» en Disertaciones y opúsculos, I, Madrid, 1928, pág. 31. Stern ya señaló en 1948 ( op. cit., 150, nota 2) el error de Ribera y situó correctamente la referencia de aquel autor oriental. Cfr. al-Muqaddasī, Descriptio Imperii Moslemici, en vol. III de la Bibliotheca Geographorum Arabicorum, ed. M. J. de Goeje, Leiden, 1877 [reimpresión 1967], pág. 243.
} 
El testimonio más curioso que presentó Ribera de la difusión de «la lengua nacional» entre los musulmanes fue lo que dijo el autor cordobés del siglo XI Ibn Hazm, quien en su obra genealógica habla de una tribu árabe, los Bali, asentada en Bali (un lugar de la zona norte de Córdoba). Según la traducción hecha por Ribera del texto manuscrito, esta tribu «conservaba su lengua primitiva: no sabían hablar latín; sólo sabían hablar en árabe, no sólo los hombres, sino también las mujeres» ${ }^{56}$. Se trata de un testimonio muy curioso, pero en un sentido muy diferente del que dio a entender Ribera. Ibn Hazm dice en realidad que las gentes de esta tribu: «[viven] con sus nisbas propias; no saben hablar en lạtiniyya, sino solamente en árabe, tanto sus mujeres como sus hombres; honran al huésped y no comen cola de cordero aún en nuestros días» ${ }^{57}$.

Los Balī, como los Quḍā 'a, Gassān y Ŷudāma, se incluyen en el grupo de tribus árabes cristianas asentadas en los territorios de la antigua Siria romana, las cuales fueron llamadas musta'riba por los escritores árabes. Recientemente el profesor Urvoy ha relacionado este término con el hispánico 'mozárabe', mostrando el uso racial, religioso y lingüístico del mismo ${ }^{58}$. Es decir que lo que Ibn Hazm señalaba era que hablaban árabe los cristianos que vivían en un lugar llamado Bali y además se decían descendientes de la tribu árabe cristiana de Bali; genealogías árabes y arabización lingüística que se advierte entre los cristianos de Toledo, de Valencia o los de Alafoens (Portugal) quienes, también en la primera mitad del siglo XI, se atribuían una ascendencia árabe Gassānĩ y la mayor parte de ellos sólo hablaba árabe ${ }^{59}$.

La obsesión por encontrar referencias al latín, alusiones a la lengua 'aŷamiyya o a la presencia de esta palabra en los textos árabes fue una constante en Simonet y Ribera. Y nos explica que forzaran algunos datos como los hasta aquí citados.

\section{FUENTES DOCUMENTALES DE LA 'A $A \hat{Y} A M I Y Y A$}

Simonet formó su Glosario con un conjunto de voces que él consideró de etimología griega, latina o ibérica, sacadas de fuentes árabes (en su ma-

\footnotetext{
${ }^{56}$ Op. cit., I, pág. 34.

57 E. Terés, «Linajes árabes en al-Andalus según la «Ŷamhara» de Ibn Hazm», Al-Andalux, XXII, 1957, pág. 364, § 77. Nisba es voz árabe que significa «linaje» y lātiniyya es término técnico por «latín».

${ }^{58}$ D. Urvoy, «Les aspects symboliques du vocable «mozarabe». Essai de réinterprétation», Studia Islamica, LXXVIII, 1993, págs. 117-153.

${ }^{59}$ R. P. A. Dozy, Scriptorum Arabum loci de Abbadidis, II, Leiden, 1846-1863 [reimpresión 1992], cap. V, pág. 7, aunque en nota 23 identifica Alafoens con Dos Hermanas (Sevilla).
} 
yor parte manuscritas y por tanto difíciles de constrastar) y de la toponimia citada en los registros y documentos de los conquistadores cristianos. Para ello violentó el significado de la voz 'âyamiyya, que quiere decir literalmente 'no árabe' y que se aplicaba en particular a la lengua persa.

Los filólogos posteriores han rechazado como mozarabismos las voces que proceden de los vocabularios árabes medievales, pues consideran, a pesar de sus posibles o evidentes etimologías románicas, que pertenecen al habla árabe ${ }^{60}$. Por la misma razón y al margen del abuso al incluirlas, habría que rechazar también las palabras extraídas por Simonet de los diccionarios modernos de los dialectos del norte de África y de Oriente ${ }^{61}$.

Hecha la salvedad de los glosarios árabes medievales, hasta ahora se siguen aceptando como «mozarabismos», además de la onomástica sacada de fuentes árabes y cristianas, los elementos léxicos hallados en los libros de medicina y farmacología.

Como es bien sabido por los historiadores de la Ciencia, estos tratados, entre los que se halla el Glosario editado por Asín, contienen sinonimias de los diversos nombres de una misma sustancia. Farmacólogos y médicos medievales, por ignorancia o porque no les interesaba detallarlo, utilizaban muy a menudo la voz genérica 'aŷamiyya para señalar su origen no árabe. Algunos para mostrar su erudición indicaban con frecuencia, antes o después de estas voces, su etimología (que a menudo es incorrecta): griego antiguo, bizantino, persa, lenguas de la India, siríaco, hebreo, bereber o latín (clásico y vulgar), lenguas todas ellas que pueden aparecer en otros autores sólo como aŷamiyya. No se trata, por tanto, de recopilaciones de voces evolucionadas de una lengua viva románica, sino de copias de materiales de etimologías diversas, conservados en obras de transmisión culta y libresca.

Hay que advertir también que en los escritos árabes de al-Andalus el conjunto de nombres no árabes que designan drogas procede en su mayor parte de los autores orientales de los siglos IX y x. Tal es el caso - recogido por Simonet- de la voz fušăl (catalán fusell, castellano husillo), citada al parecer en la obra del oriental del siglo IX Ibn Māsawayh, que es mencionada por los autores andalusíes ${ }^{62}$.

${ }^{60}$ D. A. Griffin, «Mozarabismos del «Vocabulista» atribuido a Ramón Martí», Al-Andalus, XXIII, 1958, págs. 276-277. Igual opinión sin remitir a Griffin, A. Galmés de Fuentes, Dialectología mozárabe, Madrid, 1983, pág. 19; igualmente, sin referirse a Griffin ni a Galmés, L. Peñarroja, El mozárabe de Valencia. Nuevas cuestiones de fonología mozárabe, Madrid, 1990, pág. 51.

${ }^{61}$ Entre las que se encuentra «yúca». R. Menéndez Pidal, Orígenes..., § 44 sospechaba que «de los mozárabes tomaría también el árabe marroquí la voz yuka 'lechuza' registrada en un vocabulario de comienzos del siglo XIX».

${ }^{62}$ Cfr. F. J. Simonet, Glosario, s.v. fuxiél y fuxxiél (ed. citada, II, pág. 236), transcribe la cita de Ibn Buklāriš donde éste afirma que copió el nombre de una obra del autor oriental. 
Olvidando el contexto científico, la tradición grecolatina y la aportación siríaca y persa a esta disciplina, se ha cometido la imprudencia de identificar como «romance hispano» cualquier término al que acompañe la voz 'aŷamiyya o 'aŷamiyyat al-Andalus. Así se ha incrementado el acervo mozárabe con nombres que en realidad son griegos, persas, siríacos, etc., y aunque no falten los latinos, éstos responden en realidad a una tradición culta y no a una pronunciación viva.

A este respecto se podrían aducir muchas voces griegas que, tanto en el Glosario de Simonet como en el editado por Asín, aparecen como nombres presuntamente romances. A título de ejemplo, en Simonet Óbga y Túri (por

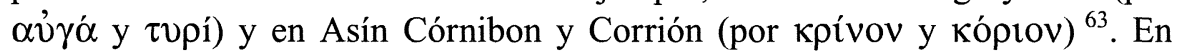
este último es sorprendente - porque implica al copista o al autor andalusí y a su editor moderno- el caso de un término, traducido en el texto árabe por kāsir al-hayar ('rompe piedras'), que no es otra cosa sino una mala copia del segundo componente -en letras árabes- del griego $\lambda \mathrm{l} \theta$ ós $\pi \varepsilon \rho \mu o v$, es decir de una planta saxifraga. En manos de Asín se ha convertido en el supuesto romance franne firrino ${ }^{64}$.

Sin valorar la aportación científica de una obra anónima (de cuya lectura se desprende que el autor y copista no conocían el griego, ni el latín, ni el siríaco, ni el persa y casi nada de etimologías), sin tener en cuenta tampoco las evidentes voces griegas y la tradición árabe de esta disciplina botánica, manipulando a su antojo la redacción del texto árabe y dando por sentado que 'ayamiyya quería decir 'romance hispano', Asín obtuvo un total de 726 palabras como resultado de leer lo que le interesaba y apoyándose muchas veces en las erráticas, dudosas, hipotéticas e inventadas palabras recogidas por Simonet ${ }^{65}$.

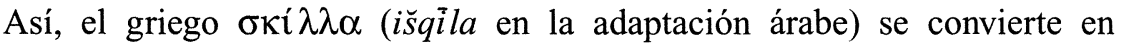
Ašíglo (Asín n. ${ }^{\circ} 49$ ); vó $\rho \theta \eta \xi$ ('varas, férula') en Pérticaš -inspirándose en la traducción árabe del término griego (n. $\left.{ }^{\circ} 429\right)$-; $\alpha \kappa \alpha \lambda \eta ́ \varphi \eta$ en Ortica

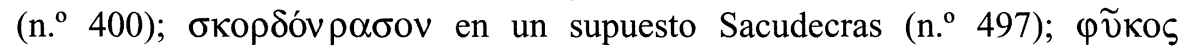
('ova, alga', en árabe țuhlub) en Babóš (n. $\left.{ }^{\circ} 57\right)$; $\varphi$ õvı $\xi$ en Formicaš (n. ${ }^{\circ}$

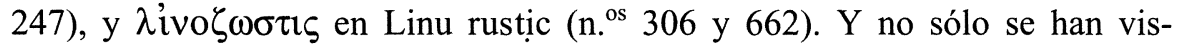
to manipuladas las voces griegas, sino también las latinas. De este modo, sin enmendar el muy corrupto texto árabe, obtuvo de una única forma $<$ barbāšquh> del latín verbascum el inexistente árabe al-rašã qa y los ro-

\footnotetext{
${ }^{63}$ Fácilmente identificables en grafia árabe para cualquier mediano conocedor de la terminología griega.

${ }^{64}$ M. Asín Palacios, Glosario de voces romances registradas por un botánico anónimo hispano-musulmán (siglos XI-XII), Madrid-Granada, 1943 [facsímil, Zaragoza, 1994] n. ${ }^{\circ}$ 249, cuyo equivalente botánico sería el cardo silvestre (Onopordon acanthium L.); pero compárese con el n..$^{\circ} 499$, identificado con el Lithospermum officinale $L$.
} 
mances: Vaiza-bazino, Vaizaš-mano, Barba nancha y Verbenaqa. $\mathrm{Y}$ al lentisco (<lintišquh $>$ y $<$ linuh tūšquh $>$ ) lo convirtió en Lena rústica. Convendría abstenerse de usar este Glosario hasta que se haga una revisión a fondo ${ }^{66}$.

A este respecto es preciso avisar del despropósito cometido por Simonet (secundado después por Asín y otros) al interpretar a su capricho el ductus consonántico de los manuscritos árabes. Pero no se han limitado a esto, sino que han convertido un único ductus consonántico árabe en dos -0 más- voces «romances» sin advertir al lector.

El número de casos en que eso sucede es tan abundante que no vamos a abrumar al lector con infinitas citas de palabras absurdas. Por ejemplo, y a título de inventario, podemos aducir que Simonet fabrica a partir de una única cita manuscrita más de una entrada de su Glosario, algunas tan dispares como Bércha canína/Uva canína/Yérba noquíxa, Quécho-quéicho/Túri, Tágar/Págar, Calcarión-Calcarixta/Folicanón/Gallocresta, Fíco/Fónco-Fóncox, Capára/Tháparax. También en Asín: Barbella-Barbelya/Yerbelya. Añándanse además la palabras persas leídas a lo «mozárabe», como Exco-bardín y Xácca vénto en Simonet o Zanbuca en Asín ${ }^{67}$.

Por otra parte, se ha pretendido que cuando los farmacólogos Ibn Buklāriš e Ibn al-Bayțār hacen referencia a una voz de la 'ayamiyya de determinada zona peninsular, ésta se corresponde al habla «mozárabe» de la época y lugar en que vivieron: Zaragoza en el siglo XI y Málaga en el XIII. Tal sería el caso de Bentónica o Bertónica (en las transcripciones de Simonet) una voz que, según aquellos farmacólogos, pertenecía al aljamiado de la región de Zaragoza y Valencia. Desgraciadamente no se trata de una pronunciación propia de los siglos XI o XIII, como han pretendido Simonet $\mathrm{y}$ otros. Ya a principios del siglo $\mathrm{x}$ se encontraba con la

65 Basta confrontar ligeramente las afirmaciones del Glosario de Asín con el de Simonet y con el texto completo de la reciente edición de los dos ms. que conservan la obra para advertir los despropósitos.

${ }^{66}$ El Glosario de Asín debería enmendarse y corregirse (mejor - tal vez- ignorarlo). No ayuda mucho confrontar sus entradas con la meritoria edición hecha por Al-Jațābī, M.A-'A. 'Umdat al-tabïb fi ma'rifat al-nabāt li-Abi-l-Jayr al-Išbïlī, Rabat, 1990, 2 vols. El profesor AlJațāōī ha eliminado y resuelto muchos errores, pero todavía quedan. Hay que advertir que la referencia a folios de Asín parece que también está equivocada. A título de ejemplo: f. $43 v$ en pág. 96 de la ed.; f. $35 v=$ pág. 105 ; f. $49 r=$ pág. 113 ; f. $41 r=$ pág. 123 , etc. Respecto a los materiales de este Glosario, ya señaló con sorpresa su «forma bastante moderna» D. A. Griffin, loc. cit., pág. 280.

67 Todos los ejemplos citados han sido seleccionados para que un lector que ignore la lengua árabe pueda comprobar las afirmaciones con la sola consulta de ambos Glosarios. Se omiten las denominaciones científicas modernas ya que poco tienen que ver con la concepción botánica medieval y obligarían a ampliar excesivamente el número de notas con advertencias sobre la discrepancia en determinadas identificaciones. 
misma forma gráfica y adscripción territorial en otros escritores andalusíes anteriores ${ }^{68}$.

$\mathrm{Y}$, curiosamente, al igual que los autores árabes, cuando Plinio habla de esta misma planta griega señala que en Hispania le decían vettones, mientras que en la Galia le llamaban vettonica ${ }^{69}$. Parece evidente que esa voz que se imputa a la 'aŷamiyya es transcripción - como casi siempre - de un término técnico de alguna obra no árabe, y que además la Galia se ha identificado con Zaragoza y después se le ha añadido Valencia.

Respecto a la «toponimia mozárabe», hace tiempo que quien esto escribe señaló que ciertos nombres de lugar de difícil explicación etiquetados como mozárabes no justifican la supervivencia de las hablas románicas en al-Andalus ${ }^{70}$; como tampoco los topónimos valencianos de etimología árabe son prueba de que el árabe todavía se hable hoy, ni de que se hablara en los siglos XIX, XVIII o XVII. Se trata en ambos casos de un material lingüístico secundario ${ }^{71}$. Por esa razón he subrayado que la definición de Coromines ${ }^{72}$ de que los topónimos mozárabes son «els noms no aràbics però anteriors a la Reconquesta, l'origen pre-romà, romà o germànic dels quals no es pot provar clarament», es una muestra de la arbitrariedad y abuso con que se aplica esta denominación.

Lo mismo puede decirse de la onomástica presuntamente «románica» de los musulmanes de al-Andalus. Algunas fuentes árabes indican que los apodos de ciertos personajes no eran de etimología árabe. De la mayor parte de ellos tan sólo recogen la traducción, sin transcribir el nombre románi$\mathrm{co}^{73}$. Pero aunque pueda haber existido alguno, hay muchos que han sido inventados por la erudición moderna a partir de un ductus consonántico no

${ }^{68}$ Véase C. Barceló, «Romance Lexicon in Pharmacological Treatises written in Muslin Spain: its origin and transmission» (en prensa).

${ }^{69}$ Plinio, Historia Naturalis, lib. xxv, cap. 8, apud Simonet. Es muy frecuente en los farmacólogos y botánicos andalusíes la confusión de las tres diferentes plantas citadas por Dioscórides (cestrón, camedrio y teucrio, que recibían el mismo nombre latino bajo la forma $<$ bantrunqa $>$ y demás variantes ortográficas).

${ }^{70}$ C. Barceló, «La toponímia àrab», Materials de toponímia II. (Mestratge de Toponímia. 1990-1991), Valencia, 1995, pág. 1133. Véase también, C. Barceló, «Penàguila: un topònim àrab», A Sol Post, 3, 1991, págs. 39-44.

${ }^{71}$ No se intenta aquí negarle valor a muchos y excelentes trabajos sobre Toponimia que ayudan a conocer mejor aspectos dialectales apenas documentados a través de otros materiales. Se niega su valor como prueba de la supervivencia de un habla románica.

${ }^{2}$ J. Coromines, Estudis de Toponímia Catalana, I, Barcelona, 1965, pág. 251. El subrayado es nuestro.

${ }^{73}$ Hicieron uso de la Onomástica Simonet y Ribera. Si los autores árabes ofrecieran este precioso dato tendríamos multitud de ejemplos recogidos en los manuales. Desgraciadamente el número de veces que esto sucede no pasa del de los dedos de una mano; y de aquellos viejos nombres romances lo único que casi siempre nos transmiten es su traducción al árabe. 
vocalizado, por ejemplo: al-qumla 'piojo' [grafía <al-qmlh>] que Simonet convirtió en un mozárabe al-Qamalluh (al-camello) [grafia <al-qmlh>] ${ }^{74}$. Pese al silencio de los autores árabes sobre la etimología latina de algunos nombres de personajes musulmanes, ésta puede sospecharse para unos cuantos letrados de los siglos VIII, IX o posteriores, pero en todos los casos se tratará de especulaciones.

Como en la zona valenciana las fuentes árabes de la 'âyamiyya son nulas, se recurre a la Onomástica ${ }^{75}$; ahora bien, no siempre espigada en documentos latinos y romances de la conquista o en obras árabes (geográficas y biográficas) sino en los mapas y repertorios modernos ${ }^{76}$.

\section{EL CANTO DE SIRENA DE LAS «CANCIONCILLAS MOZÁRABES»}

No es posible mostrar aquí todas las manipulaciones hechas a las fuentes árabes, como las que hasta aquí se han señalado. Fruto de leer las letras árabes como si fueran latín o cualquier otro lenguaje románico imaginario se ha ido formando el corpus de las llamadas - sin propiedad«cancioncillas mozárabes».

A pesar de todos los absurdos y contradicciones, desde 1948 hay abierto un intenso debate sobre el origen y significado literario y lingüístico de ciertos versos contenidos en composiciones poéticas (de nombre muwašs̆ realizadas en lengua árabe y hebrea. Se conocen por el nombre técnico de jarcha, adaptación del dado por los árabes a la coda del poema.

Gracias al inventario de muwašs̆aḥāt árabes de los siglos XI al XIV (alrededor de 625) se ha podido establecer que la jarcha de 252 está redactada en árabe clásico, la de 281 en coloquial y la de 46 (el 7\% del total) ofrece alguna palabra próxima al romance, pero sólo en no más de 4

\footnotetext{
${ }^{74}$ F. J. Simonet, Glosario, s.v. Caméllo; ejemplo recogido también por J. Ribera, loc. cit., I, pág. 30. Sobre el personaje, Ibn al-Abbār, Takmila, ed. Codera, II, 434 b. 1240 . Se trata del cordobés 'Abd Allāh bn Bakr al-Kilā'ī, muerto a mediados del siglo IX. A pesar de los esfuerzos de Simonet, no llegan a 150 los nombres propios de persona supuestamente «mozárabes» recogidos en su Glosario y una buena parte corresponde a individuos que vivieron en el siglo IX o a mozárabes de Toledo.

${ }^{75}$ El primer intento en A. Galmés de Fuentes, «El mozárabe levantino en los libros de los Repartimientos de Mallorca y Valencia», Nueva Revista de Filología Hispánica, IV, 1950, págs. 313-346, recogido — sin cambios- en Dialectología mozárabe, Madrid, 1983, págs. $117-162$.

${ }^{76}$ Como hace L. Peñarroja Torrejón, El mozárabe de Valencia. Nuevas cuestiones de fonología mozárabe, Madrid, 1990. Véase mi recensión a esta obra en Al-Qanțara, XIII, 1992, págs. 290-293 y Llengua \& Literatura, 5, 1992-1993, págs. 696-698; también las de A. Galmés de Fuentes, en Aljamía, 4, 1995, págs. 62-63, y H.-R. Singer, en Journal of Arabic Linguistic, XXIX, 1995, págs. 91-93.
} 
$(0,6 \%)$ hay cierto consenso de que fueron escritas íntegramente en esta lengua ${ }^{77}$. De la serie hebrea se conservan alrededor de 150 poemas entre los siglos XI y XIII, de los que 27 (18\%) presentan jarcha de estas características ${ }^{78}$.

De esas pretendidas 73 codas «románicas» se consideran diferentes 59, pues el resto se repite en otros poemas árabes y hebreos. Son anónimas 26 (11 árabes y 5 hebreas) y las 47 restantes obras de 23 autores (16 árabes y 7 hebreas) que vivieron en los siglos XI (11 árabes y 3 hebreas), XII (4 árabes y 3 hebreas) y XIII ( 1 árabe y 1 hebrea). No hay consenso por lo que se refiere al cómputo de estas jarchas, ya que basta la presencia de una única voz que se considere «románica» para que se incluya en el recuento, aunque el resto de los versos esté íntegramente en árabe o hebreo.

Pero el debate no se centra únicamente en la lengua de las jarchas, sino en su origen (árabe, hebreo o romance), métrica (árabe o romance), rima (árabe o romance), temática (cristiana, judía o árabe) e incluso interpretación musical. De momento los entendidos no se ponen de acuerdo, pues como dice Hitchcock: «cuando se tienen en cuenta las diversas interpretaciones ofrecidas por los críticos, es bastante patente la falta de objetividad» ${ }^{79}$.

Se observará que a lo que Hitchcock le llama la atención «son las supresiones arbitrarias de fragmentos del texto primitivo; los cambios sutiles, y no tan sutiles, de varias frases y de la misma forma de algunas palabras» ${ }^{80}$, pero si (como nosotros) hubiera analizado el trabajo de Simonet y de Asín, habría advertido que el método sigue siendo el mismo. Y no cabe más que preguntarse si el callejón sin salida en el que se encuentran actualmente los versados en esta materia no es fruto de haber partido de una premisa falsa: 'aŷamiyya, ergo romance.

Afortunadamente no se conocen «jarchas valencianas», aunque se presenten como tales las que fueron compuestas por personajes nacidos en es-

77 El cómputo de estas composiciones poéticas es muy dispar. He optado por aproximar los datos ofrecidos por A. Jones, "OCCAM. Computer-based Study of the Muwašša and the Kharja», Actas del Primer Congreso Internacional sobre Poesía Estrófica Árabe y Hebrea y sus Paralelos Romances, Madrid, 1991, pág. 189; los de M. Bencheneb, «Muwashshah"», Encyclopédie de l'Islam [2." ed.], y los de M. Al-Ghdiri, «Les "Muwaššah" Andalous: Tradition et innovation» [en árabe, al-muwaššahāt al-andalusiyya bayna al-ibdā' wa-l-ittibā' intịlāqan min al-jaraȳāt al-muta" ama bi-l-'ibārä̀t al-'âyamiyya], Revue d'Etudes Andalouses, 13, 1995, pág. 42.

${ }_{78} \mathrm{Me}$ ha resultado más difícil establecer el número total de muwašs̆ahāt en hebreo. L. Díez Merino, Aljamias judeomozárabes (Jarchas hispanohebreas), Barcelona, 1996, no lo menciona en ningún momento, pero espigando datos en las págs. 39-44 aparecen los mismos números que en el artículo de Stern ya citado.

${ }_{79}$ R. Hitchcock, «Las kharajät romances, de nuevo en el banquillo», Poesía Estrófica, Madrid, 1991, pág. 170.

80 Ibidem. 
tas tierras pero que vivieron fuera de sus lugares de origen ${ }^{81}$. Y por tanto, tan conjetural es suponer que el habla románica de los versos de estos poetas refleja el valenciano como que refleja el de la zona en que fueron escritas. Pasará mucho tiempo antes de que todos nos demos cuenta de que se trata de cantos de sirena.

\section{EL COMODÍN DEL BILINGÜISMO DE AL-ANDALUS}

Porque esos versos, si son romances ${ }^{82}$, se encuadran perfectamente en la situación lingüística de al-Andalus a mediados del siglo x. No se puede negar que hay noticias (como mucho una docena) que muestran a algunas personas hablando una lengua no árabe, pero en tiempos muy primitivos, todo lo más hasta el gobierno del califa 'Abd al-Rahmãn III ${ }^{83}$. Después, el silencio; o las pruebas en contrario, como los cristianos arabizados de Toledo, Córdoba o Portugal. Eso es exactamente lo que quiere decir «mozárabe», como ha demostrado el profesor Urvoy y se ha explicado antes: tribu árabe cristiana que además habla árabe.

Es también en este mismo siglo XI cuando la Primera Crónica General cita a los cristianos arabizados de Valencia, es decir cuando se ha detenido el proceso de bilingüismo. Resultaría, pues, sorprendente que Ibn Sida (nacido en Murcia y muerto en Denia en 1066) se refiriera al habla románica

${ }^{81}$ Así lo señaló G. Colón Domènech, El léxico catalán en la Romania, Madrid, 1976, págs. 161-163 (trad. catalana, Valencia, 1993, págs. 140-142), contradiciendo unas afirmaciones de Sanchis Guarner; también lo ha señalado F. Corriente, «Las jarchas valencianas. (Algunas xarajāt romances en muwaššahăt de poetas andalusíes de origen valenciano)», En torno al 750 aniversario. Antecedentes y consecuencias de la conquista de Valencia, I, Valencia, 1989, págs. 227-236. Las menciona L. Peñarroja, El mozárabe de Valencia, págs. 98-111, pero no utiliza sus materiales por considerar que no representan el habla «mozárabe» de Valencia.

${ }^{82}$ Disponemos ahora de dos recientes intentos de interpretación de estos textos, que se acompañan del estudio de sus rasgos gramaticales, desde supuestos diferentes: por una parte el de A. Galmés de Fuentes, Las jarchas mozárabes. Forma y significado, Madrid, 1994, que sigue fiel a sus postulados mozárabes; por otro y con planteamientos distintos, F. Corriente, «Nueva propuesta de lectura de las xarajāt de la serie árabe con texto romance», Revista de Filología Española, LXXIII, 1993, págs. 25-41, así como F. Corriente y A. Sáenz-Badillos, «Nueva propuesta de lectura de las xarajāt con texto romance de la serie hebrea», Revista de Filología Española, LXXIV, 1994, págs. 283-289, y F. Corriente, «El ideolecto romance andalusí reflejado por las xarajāt», Revista de Filología Española, LXXV,'1995, págs. 5-33.

${ }^{83}$ El grueso de los testimonios de fuentes árabes aportados por Ribera sobre el uso de una lengua no árabe por parte de algún personaje de Córdoba corresponde a este período (siglos VIII-X). P. Guichard, Al-Andalus. Estructura antropológica de una sociedad islámica en Occidente, Barcelona, 1976, pág. 177, nota 114, propone que se invierta la hipótesis, ya que los ejemplos aducidos son considerados por los autores árabes como algo excepcional, es decir mostrarían la ya profunda arabización de los andalusíes. 
de Murcia en el prólogo de su diccionario ideológico del árabe, como pretendió Ribera ${ }^{84}$. En 1968 Makki entendió que Ibn Sỉda se lamentaba de tener que vivir "con personas que hablaban mal el árabe» donde Ribera había traducido «con personas que hablan el romance» ${ }^{85}$. No extraña, después de todo lo dicho, que éste forzara la traducción en beneficio de su tesis. Y por ello resulta más chocante leer en la tan citada obra de Ibn Sida lo que éste entendía por aŷamiyya y que se ha escamoteado a los investigadores, esto es: la lengua griega y el persa ${ }^{86}$.

El bilingüismo de al-Andalus, que no puede negarse para los primeros siglos, es una buena coartada para justificar aquello que se quiera justificar. Así los mozárabes bilingües habrían introducido los arabismos en las lenguas románicas norteñas ${ }^{87} \mathrm{y}$ los musulmanes bilingües pudieron tener acceso a la cultura grecolatina peninsular, traducirla y aprovecharse de ella ${ }^{88}$.

Visto todo lo que antecede no nos ha de causar extrañeza que, a base de insistir durante un siglo sobre la pervivencia de la «lengua nacional» en territorios islámicos, haya personas bien pensantes que acepten sin reservas que, casi desaparecidos los mozárabes, los «musulmanes bilingües» del territorio actualmente valenciano transmitieron su lengua románica a los conquistadores (que hoy se denomina «valenciana»). Todo ello sin contaminarse la «lengua nacional» más que con el artículo árabe [al-], en topónimos como Alpont, Alpatró, Almonacid o Alcampo o enriqueciéndose con arabismos y otros tantos «mozarabismos» castellanos, aragoneses e incluso catalanes.

Pero por mucho que el «mozárabe» tenga una apariencia real en los libros de historia de la lengua, un análisis mínimamente serio muestra que sólo ha existido en la imaginación de los que la crearon. Se presenta con

\footnotetext{
${ }^{84}$ J. Ribera, Disertaciones y opúsculos, I, pág. 100 nota. En favor del habla «mozárabe» de Murcia utilizó este dato J. García Soriano, Vocabulario del dialecto murciano, Madrid, 1932 , pág. xxx y notas 1-4. Este testimonio fue vinculado por primera vez al habla «mozárabe» de Denia por A. Ubieto, Orígenes del Reino de Valencia. Cuestiones cronológicas sobre su conquista, Valencia, 1975, pág. 91. Igual argumento en L. Peñarroja, El mozárabe de Valencia, págs. 145-146, sin aludir a la adscripción murciana hecha por Ribera.

${ }^{85}$ M. A. Makkī, «Ensayo sobre las aportaciones orientales en la España musulmana y su influencia en la formación de la cultura hispano-árabe», Revista del Instituto de Estudios Islámicos de Madrid, XI-XII, 1963-1964, pág. 95 (tirada aparte, Madrid, 1968, pág. 257). Igual interpretación en D. Bramon, «Una llengua, dues llengües, tres llengües», en Pere Sisè. Raons d'identitat del País Valencià (Pèls i senyals), Valencia, 1977, pág. 20 y C. Barceló, «La llengua àrab al País Valencià (segles VIII al XVI)", Arguments, 4, 1979, pág. 125, nota 8.

${ }^{86}$ Ibn Sīda, Kitāa al-Mujașsaṣ; la cita de Ribera se encuentra en vol. I, pág. 14 (Būlāq 1316H. [1898]) y el estudio de palä̆ras 'aŷamiyya en vol. 14, págs. 39-44 (Būlāq 1320H. [1902]).

${ }^{87}$ R. Menéndez Pidal, Orígenes del español, §104 y 105.

${ }^{88}$ A modo de ejemplo, véase la crítica a esta tesis por lo que respecta a los agrónomos andalusíes en B. A. Attié, «Ibn Ḥağğăğg, était-il polyglotte?», Al-Qantara, I, 1980, págs. 243-261.
} 
apariencia de tesis demostrada para convencer de turbias y peregrinas teorías: bien del mantenimiento en un lugar determinado de características desconocidas del ibérico o del sorotáptico, para justificar la cuña del castellano sobre otras lenguas o la existencia de una ignorada lírica o de una primitiva épica hispánica, bien para demostrar que el valenciano es una lengua más antigua que el catalán o que siempre han existido españoles, valencianos, andaluces -o lo que se quiera - fieles a sus raíces cristianas.

Si a nadie se puede negar el derecho a jugar y entretenerse elaborando una fonética, lexicografía o toponimia valenciana ficticias, sí es obligado reclamarle que avise a sus posibles lectores que: se encontrarán ante una lengua ad hoc para uso de determinadas ideologías; se enfrentarán a una lengua poética de fantasía en la que verbos, pronombres, morfología, sintaxis y fonética funcionan por antojo; y se deleitarán con una lengua idílica de fonemas, voces y topónimos, pero sin verbos, sin pronombres, sin morfología, sin sintaxis... y $\sin$ hablantes. 